\title{
Methodical approach to assessing the volume of youth labour migration in the states of the Eurasian Economic Union
}

\author{
Alena A. Veselko \\ Peoples' Friendship University of Russia (RUDN University) \\ 6 Miklukho-Maklaya St., Moscow, 117198, Russian Federation
}

\begin{abstract}
Labour migration plays an integral role in the socio-economic development of any country; it affects both the structure and the size, the social and economic spheres of society. Therefore, it is necessary to monitor the migration process, because, in the future, it can have a positive impact on the economic growth of the country. The article proposes a model for macro-economic assessment of the volume of youth labor migration in the states of the Eurasian Economic Union (EAEU). The model is based on the ideas of labor migration in the form of a random Markov process with discrete states and continuous time. The chain states are interpreted as the labour market of the youth of the respective EAEU states, and the transition rates reflect the attractiveness of these markets for young people from different states. This made it possible to take into account the inherent uncertainty and inertia in the process of youth migration.
\end{abstract}

Keywords: Eurasian Economic Union; labour markets; youth labour migration; methodical approach; forecasting; evaluation

\section{Introduction}

The youth labor market is an independent, integral segment of the collective labor market. It stands out based on functioning in the society of young people as a particular socio-demographic group that has particular needs and interests and also occupies a specific role in the reproduction of labor relations. The young population, university graduates, make up a significant part of the working-age population. Besides, they play a crucial role in the reproduction and development of labor resources and are the main innovative potential. In general, the creation of decent jobs for young people who enter the labor market every year is an essential element of development towards the prosperity of the national economy. At the same time, the youth labor market in the EAEU countries is not yet sufficiently developed. At the same time, the EAEU is a promising integration association. Its labor market requires forecasting and identifying the primary vectors for further development, improving both the existing labor market management system of

(C) Veselko A.A., 2019

(c) (i) This work is licensed under a Creative Commons Attribution 4.0 International License https://creativecommons.org/licenses/by/4.0/ 
the participating countries, and finding opportunities and practical tools for integrating the national labor markets of new participants in the collective labor space of the EAEU (Anisiforov et al., 2012; Silkina, 2010; Anisimov et al., 2015; Saurenko et al., 2019; Chvarkov, 2016).

The formation of the rational youth policy of the EAEU states is not possible without an a priori assessment of the results of political decisions. An essential element of this assessment is forecasting the volume of youth labor migration. The volumes of labor migration in the EAEU countries depends on a sufficiently large number of factors that characterize both the youth policy of the states and their inherent economic and demographic conditions. In the system of these factors, the leading place belongs to such factors as the volume of labor markets of young people of the states, the volume of labor resources of young people, the degree of satisfaction of the needs of young people in each of the states. Consequently, the model for macroeconomic assessment of the volume of labor migration and, in general, the youth policy pursued by the EAEU states, first of all, it should take into account the indicated main factors (Rodionova et al., 2016; Anisimov et al., 2015; Boiko et al., 2008; Blau et al., 2017; Anisimov et al., 2017). The development of such a model is the purpose of this article.

\section{The general scheme of the migration process}

A generalized scheme of possible labor migration of young people within the EAEU is shown in Figure.

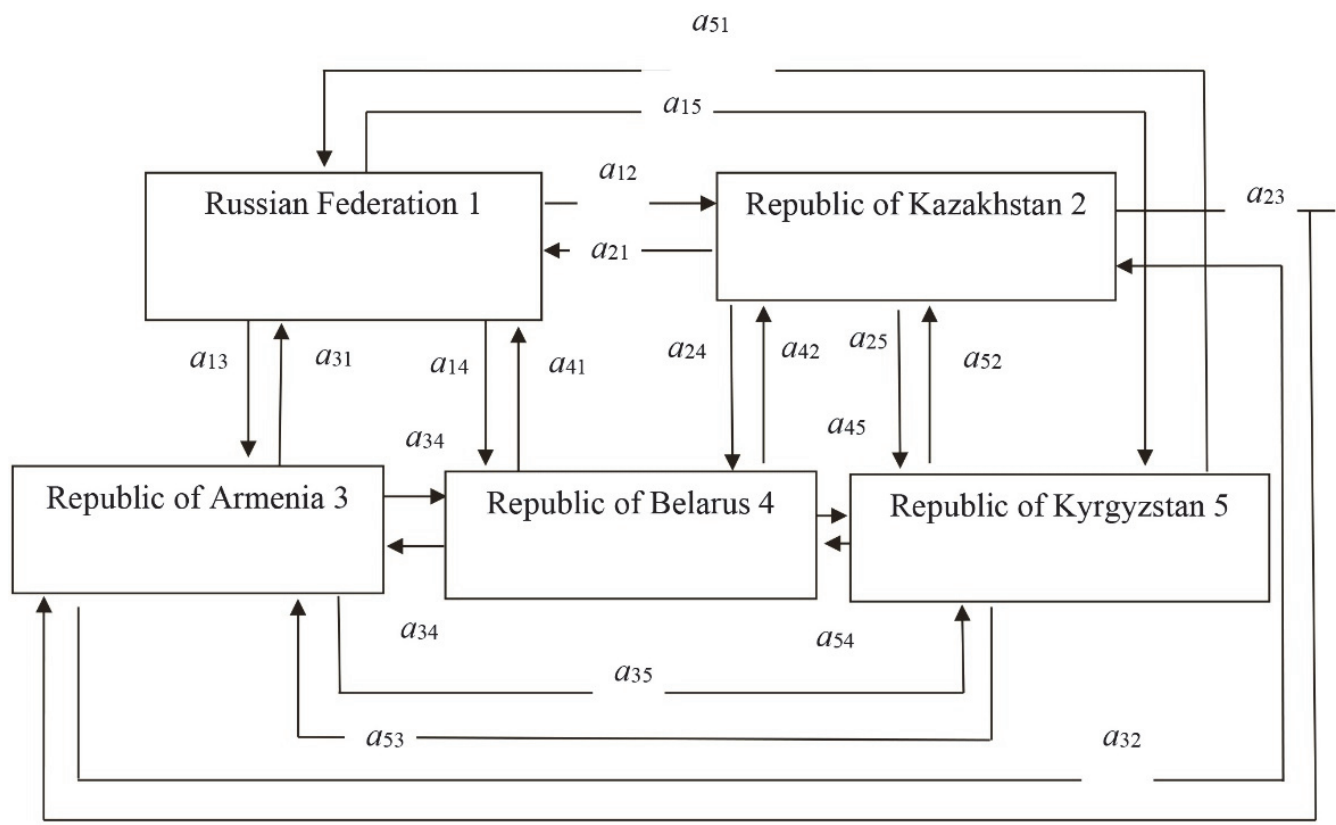

Figure. Generalized scheme of possible labor migration of young people within the framework of the EAEU

Source: Compiled by the authors. 
Within the framework of such a schematization, the attractiveness of the labor market in terms of youth migration can be represented as a random Markov process of wandering representing points over a variety of states $(i=1,2,3,4,5)$. Here, the state $i=1$ corresponds to the youth labor market of the Russian Federation, $i=2$ to the youth labor market of the Republic of Kazakhstan, $i=3$ to the youth labor market of the Republic of Armenia, $i=4$ to the youth labor market of the Republic of Belarus, $i=5$ to the youth labor market of the Republic Kyrgyzstan.

The attractiveness of the labor market of each of the states is interpreted as the probability of finding the representing point in the corresponding state.

\section{Model of the dynamics of the attractiveness of youth markets of the EAEU states}

In the interests of a formalized presentation of the process of youth labor migration in the EAEU, let us designate: $p_{i}$ - the probability of finding the representing point in the state $i(i=1,2,3,4,5) ; a_{i j}-$ is the intensity of the transition of a representing point from the state $i(i=1,2,3,4,5)$ to the state $j(j=1,2,3,4,5)$, where $i \neq j$.

Then, the process in question is formally described by the following system of Kolmogorov differential equations:

$$
\left\{\begin{array}{l}
\frac{d p_{1}(t)}{d t}=-\left(a_{12}+a_{13}+a_{14}+a_{15}\right) p_{1}(t)+a_{21} p_{2}(t)+a_{31} p_{3}(t)+a_{41} p_{4}(t)+a_{51} p_{5}(t) \\
\frac{d p_{2}(t)}{d t}=a_{12} p_{1}(t)-\left(a_{21}+a_{23}+a_{24}+a_{25}\right) p_{2}(t)+a_{32} p_{3}(t)+a_{42} p_{4}(t)+a_{52} p_{5}(t) \\
\frac{d p_{3}(t)}{d t}=a_{13} p_{1}(t)+a_{23} p_{2}(t)-\left(a_{31}+a_{32}+a_{34}+a_{35}\right) p_{3}(t)+a_{43} p_{4}(t)+a_{53} p_{5}(t) \\
\frac{d p_{4}(t)}{d t}=a_{14} p_{1}(t)+a_{24} p_{2}(t)+a_{34} p_{3}(t)-\left(a_{41}+a_{42}+a_{43}+a_{45}\right) p_{4}(t)+a_{54} p_{5}(t) \\
\frac{d p_{5}(t)}{d t}=a_{15} p_{1}(t)+a_{25} p_{2}(t)+a_{35} p_{3}(t)+a_{45} p_{5}(t)-\left(a_{51}+a_{52}+a_{53}+a_{54}\right) p_{5}(t)
\end{array}\right.
$$

With the condition of rating:

$$
p_{1}(t)+p_{2}(t)+p_{3}(t)+p_{4}(t)+p_{5}(t)=1 .
$$

For a constructive representation of the model (1), (2), it is necessary to determine the intensities $a_{i j}$ of transitions representing a point from the state $i(i=1$, $2,3,4,5)$ to the state $j(j=1,2,3,4,5), i \neq j$. In the interests of their determination, we introduce the values $b_{i}(i=1,2,3,4,5)$, reflecting the average level of real wages of young people in the countries under consideration. These values can be determined based on the ratio

$$
b_{i}=\frac{z_{i}}{K_{i}}, \quad i=1,2,3,4,5,
$$

where $z_{i}-$ is the average salary of young people in the $i$-th state; $K_{i}-$ is the cost of the consumer basket of youth in the $i$-th state.

Then the intensities of the transitions $a_{i j}$ of the transitions representing the points from the state $i(i=1,2,3,4,5)$ to the state $j(j=1,2,3,4,5), i \neq j$, are determined by the relation 


$$
a_{i j}=R \frac{b_{j}}{b_{i}}, \quad i, j=1,2,3,4,5 ; \quad i \neq j
$$

where $R-$ is the scale factor.

In model $R$, it is equal to the annual volume of youth labor migration to the EAEU. As initial conditions for the integration of the system of differential equations (1), the following values can be taken:

$$
p_{i}(0)=\frac{N_{i}}{\sum_{i=1}^{5} N_{i}}, \quad i=1,2,3,4,5,
$$

where $N_{i}$ - is the number of employed youth in the $i$-th state.

Relations (1) - (5) are a model of the dynamics of the attractiveness of the youth markets of the EAEU states under the assumption that their labor market is closed, that is, there is no leakage of labor resources into the external ones concerning the EAEU state.

In the steady-state system (1) is reduced to the following system of algebraic equations:

$$
\left\{\begin{array}{l}
0=-\left(a_{12}+a_{13}+a_{14}+a_{15}\right) p_{1}+a_{21} p_{2}+a_{31} p_{3}+a_{41} p_{4}+a_{51} p_{5} \\
0=a_{12} p_{1}-\left(a_{21}+a_{23}+a_{24}+a_{25}\right) p_{2}+a_{32} p_{3}+a_{42} p_{4}+a_{52} p_{5} \\
0=a_{13} p_{1}+a_{23} p_{2}-\left(a_{31}+a_{32}+a_{34}+a_{35}\right) p_{3}+a_{43} p_{4}+a_{53} p_{5} \\
0=a_{14} p_{1}+a_{24} p_{2}+a_{34} p_{3}-\left(a_{41}+a_{42}+a_{43}+a_{45}\right) p_{4}+a_{54} p_{5} \\
1=p_{1}+p_{2}+p_{3}+p_{4}+p_{5}
\end{array}\right.
$$

Denote:

$$
\begin{aligned}
& -\left(a_{12}+a_{13}+a_{14}+a_{15}\right)=a_{11} ; \\
& -\left(a_{21}+a_{23}+a_{24}+a_{25}\right)=a_{22} ; \\
& -\left(a_{31}+a_{32}+a_{34}+a_{35}\right)=a_{33} ; \\
& -\left(a_{41}+a_{42}+a_{43}+a_{45}\right)=a_{44} .
\end{aligned}
$$

Then system (6) takes the form

$$
\left\{\begin{array}{l}
0=a_{11} p_{1}+a_{21} p_{2}+a_{31} p_{3}+a_{41} p_{4}+a_{51} p_{5} \\
0=a_{12} p_{1}+a_{22} p_{2}+a_{32} p_{3}+a_{42} p_{4}+a_{52} p_{5} \\
0=a_{13} p_{1}+a_{23} p_{2}+a_{33} p_{3}+a_{43} p_{4}+a_{53} p_{5} \\
0=a_{14} p_{1}+a_{24} p_{2}+a_{34} p_{3}+a_{44} p_{4}+a_{54} p_{5} \\
1=p_{1}+p_{2}+p_{3}+p_{4}+p_{5}
\end{array}\right.
$$

Or in the matrix entry form

$A P=B$,

where $A=\left[\begin{array}{ccccc}a_{11} & a_{21} & a_{31} & a_{41} & a_{51} \\ a_{12} & a_{22} & a_{32} & a_{42} & a_{52} \\ a_{13} & a_{23} & a_{33} & a_{43} & a_{53} \\ a_{14} & a_{24} & a_{34} & a_{44} & a_{54} \\ 1 & 1 & 1 & 1 & 1\end{array}\right] P=\left[\begin{array}{c}p_{1} \\ p_{2} \\ p_{3} \\ p_{4} \\ p_{5}\end{array}\right], \quad B=\left[\begin{array}{l}0 \\ 0 \\ 0 \\ 0 \\ 1\end{array}\right]$. 
$D$ denotes the determinant of the matrix $A$. Since each of the rows of the matrix $A$, by definition, has nonzero elements, then $D \neq 0$. Consequently, the system of algebraic equations is definite and has one solution. The roots of this system can be calculated using Cramer's formulas:

$$
p_{i}=\frac{D_{i}}{D}, \quad i=1,2,3,4,5,
$$

where $D_{i}$ - is the determinant of the matrix obtained from matrix $A$ by replacing the $i$-th column with vector $B$.

In general, relations (1) - (5) reflect the dynamics of the attractiveness of the EAEU states for labor migration, and relations $(6)-(10)$ reflect their ultimate attractiveness. At the same time, the limited labor markets of the EAEU states do not allow to place all labor resources within one state. Therefore, in the model of labor migration of young people, it is necessary to take into account this circumstance.

\section{Formalized view of the migration process}

It is natural to assume that markets will be filled as attractiveness decreases (Likhacheva et al., 2014; Anisimov, Gorbatov, Saurenko, 2013; Anisimov, Anisimov, 2007; Silkina, Shevchenko, 2018; Chernysh et al., 2006; Il'in et al., 2018). At the same time, the filling of each labor market is primarily carried out at the expense of national cadres. The correctness of this assumption is since each of the states is primarily interested in the preservation of their labor resources. Also, kinship and cultural ties will keep young people in their states. The shortage of labor resources of the states will be compensated by the migration of young people from other states. At the same time, the most massive migration flow should be expected from the states with the lowest average wage level of young people (Silkina, 2018; Chvarkov, Kharchekno et al., 2017; Serba, 2014; Serba, Noskov, 2015). For a formalized representation of these circumstances, we introduce the following notation:

$M=\left\{m_{1}, m_{2}, m_{3}, m_{4}, m_{5}\right\}-$ the vector of the volume of youth labor markets in the respective EAEU states;

$Y=\left\{y_{1}, y_{2}, y_{3}, y_{4}, y_{5}\right\}$ - vector of the labor force of young people in the relevant EAEU states.

Then the number of $N_{i}$ employed youth in the $i$-th $(i=1,2,3,4,5)$ state is determined by the ratio:

$$
N_{i}=\left\{\begin{array}{c}
p_{i} M^{*}, \text { если } p_{i} M^{*} \leq m_{i} \\
m_{i}, \text { если } p_{i} M^{*}>m_{i}
\end{array}, \quad i=1,2,3,4,5,\right.
$$

where $M^{*}=\sum_{i=1}^{5} m_{i}$.

To assess the national composition of young people employed in the $i$-th EAEU state, we construct a variation series of preferences for the youth labor markets of the EAEU states:

$$
p_{i}(1)>p_{i}(2)>p_{i}(3)>p_{i}(4)>p_{i}(5), \quad i=1,2,3,4,5 .
$$


We will assume that the $i$-th labor market is the most preferable for the youth of the $i$-th state. The preference of this market for the youth of other states decreases as the values of $p_{j}$ decrease $(j=1,2,3,4,5) j \neq i$. Then the shares of the youth of the EAEU states in the composition of the employed $i$-th state of the youth can be determined based on Fishburne rating for

$$
w_{i}>w_{2}>w_{3}>w_{4}>w_{5}, \quad i=1,2,3,4,5,
$$

obtained from (12) by replacing the first element by $p_{i}$.

The relation determines Fishburne rating for the variation series (13) (Lipatova, Chernysh et al., 2011; Anisimov et al., 2016; Balyasnikov, Vedernikov et al., 2015):

$$
F_{i}=\frac{5-i+2}{5 \times 2^{i}}, \quad i=1,2,3,4,5 .
$$

The quantitative values of these estimates are shown in Table 1.

Table 1

Fishburne rating for the preference of the youth labor markets of the EAEU states

\begin{tabular}{cccccc}
\hline $\begin{array}{c}\text { No element of } \\
\text { the variation } \\
\text { series }\end{array}$ & $\mathbf{1}$ & $\mathbf{2}$ & $\mathbf{3}$ & $\mathbf{4}$ & $\mathbf{5}$ \\
\hline $\begin{array}{c}\text { Fishburne } \\
\text { Rating }\left(F_{i}\right)\end{array}$ & 0.600 & 0.250 & 0.100 & 0.038 & 0.012 \\
\hline
\end{tabular}

Source: Compiled by the author.

Based on the assumption that labor markets will be filled as their overall attractiveness decreases, the procedure for determining the ethnic composition of young people employed in the $i$-th EAEU state is as follows:

1) to build a variation series (12);

2) build a Table 1 , where $N_{j}^{*}$ - the volume of labor resources of the youth of the employed state with the number $j(j=1,2,3,4,5)$ in the variation series (12); $y_{j}^{*}-$ the volume of labor resources of the state with the number $j(j=1,2,3,4,5)$ in the variation series (12); $N_{1 j}^{*}$ - the volume of labor resources of the state with the number $j(j=1,2,3,4,5)$ in the variation number, employed in the first state of the variation number.

$3)$ to determine the remains $K_{j}(1)$ of the volume of labor resources in the states after the first iteration of their distribution: $K_{j}(1)=y_{j}-N_{1 j}^{*}, \quad j=1,2,3,4,5$;

4) make a variation series (13) for the second state in the series (12);

5) make Table 3 , where $N_{j}^{*}$ - the volume of labor resources of the youth of the employed state with the number $j(j=1,2,3,4,5)$ in the variation series (13); $K_{j}^{*}(1)$ - the volume of labor resources of the state number $j(j=1,2,3,4,5)$ in the variation number (13) unallocated during the previous (first) iteration; $N_{2 j}^{*}-$ the volume of labor resources of the state with the number $j(j=1,2,3,4,5)$ in the variation number, employed in the first state of the variation number (13); 
The volume of labor resources of the states employed in the first state for a variational series

\begin{tabular}{|c|c|c|c|c|}
\hline $\begin{array}{l}\text { Number } \\
\text { in the } \\
\text { variant } \\
\text { number }\end{array}$ & $\begin{array}{l}\text { State } \\
\text { name/ } \\
\text { country }\end{array}$ & $\begin{array}{l}\text { The volume } \\
\text { of youth } \\
\text { employed } \\
\text { in the state }\end{array}$ & $\begin{array}{l}\text { Fishburne } \\
\text { rating }\end{array}$ & $\begin{array}{c}\text { The volume of labor resources } \\
\text { of the states employed } \\
\text { in the first state } \\
\text { for a variational series }\end{array}$ \\
\hline 1 & $\begin{array}{l}\text { Russian } \\
\text { Federation }\end{array}$ & $N_{1}^{*}$ & $F_{1}=0.600$ & $N_{11}^{*}=\left\{\begin{array}{ccc}N_{1}^{*} F_{1}, & \text { если } & N_{1}^{*} F_{1} \leq y_{1}^{*} \\
y_{1}^{*}, & \text { если } & N_{1}^{*} F_{1}>y_{1}^{*}\end{array}\right.$ \\
\hline 2 & $\begin{array}{l}\text { Republic of } \\
\text { Kazakhstan }\end{array}$ & $N_{2}^{*}$ & $F_{2}=0.250$ & $N_{12}^{*}=\left\{\begin{array}{ccc}N_{2}^{*} F_{2}, & \text { если } N_{2}^{*} F_{2} \leq y_{2}^{*} \\
y_{2}^{*}, & \text { если } N_{2}^{*} F_{2}>y_{2}^{*}\end{array}\right.$ \\
\hline 3 & $\begin{array}{c}\text { Republic of } \\
\text { Armenia }\end{array}$ & $N_{3}^{*}$ & $F_{3}=0.100$ & $N_{13}^{*}=\left\{\begin{array}{ccc}N_{3}^{*} F_{3}, \quad \text { если } & N_{3}^{*} F_{3} \leq y_{3}^{*} \\
y_{3}^{*}, & \text { если } N_{3}^{*} F_{3}>y_{3}^{*}\end{array}\right.$ \\
\hline 4 & $\begin{array}{c}\text { Republic of } \\
\text { Belarus }\end{array}$ & $N_{4}^{*}$ & $F_{4}=0.038$ & $N_{14}^{*}=\left\{\begin{array}{ccc}N_{4}^{*} F_{4}, \quad \text { если } \quad N_{4}^{*} F_{4} \leq y_{4}^{*} \\
y_{4}^{*}, \quad \text { если } \quad N_{4}^{*} F_{4}>y_{4}^{*}\end{array}\right.$ \\
\hline 5 & $\begin{array}{l}\text { Republic of } \\
\text { Kyrgyzstan }\end{array}$ & $N_{5}^{*}$ & $F_{5}=0.012$ & $N_{15}^{*}=\left\{\begin{array}{ccc}N_{5}^{*} F_{5}, \quad \text { если } & N_{5}^{*} F_{5} \leq y_{5}^{*} \\
y_{5}^{*}, & \text { если } & N_{5}^{*} F_{5}>y_{5}^{*}\end{array}\right.$ \\
\hline
\end{tabular}

Source: Compiled by the author.

The volume of labor resources of the states employed in the second state for a variational series

\begin{tabular}{|c|c|c|c|c|}
\hline $\begin{array}{l}\text { Number } \\
\text { in the } \\
\text { variant } \\
\text { number }\end{array}$ & $\begin{array}{c}\text { State } \\
\text { name/ } \\
\text { country }\end{array}$ & $\begin{array}{l}\text { The volume } \\
\text { of youth } \\
\text { employed } \\
\text { in the state }\end{array}$ & $\begin{array}{c}\text { Fishburne } \\
\text { rating }\end{array}$ & $\begin{array}{c}\text { The volume of labor resources } \\
\text { of the states employed } \\
\text { in the second state } \\
\text { for a variational series }\end{array}$ \\
\hline 1 & $\begin{array}{c}\text { Russian } \\
\text { Federation }\end{array}$ & $N_{1}^{*}$ & $F_{1}=0.600$ & $N_{11}^{*}=\left\{\begin{array}{lll}N_{1}^{*} F_{1}, & \text { если } & N_{1}^{*} F_{1} \leq K_{1}^{*}(1) \\
K_{1}^{*}(1), & \text { если } & N_{1}^{*} F_{1}>K_{1}^{*}(1)\end{array}\right.$ \\
\hline 2 & $\begin{array}{l}\text { Republic of } \\
\text { Kazakhstan }\end{array}$ & $N_{2}^{*}$ & $F_{2}=0.250$ & $N_{12}^{*}=\left\{\begin{array}{lll}N_{2}^{*} F_{2}, & \text { если } & N_{2}^{*} F_{2} \leq K_{2}^{*}(1) \\
K_{2}^{*}(1), & \text { если } & N_{2}^{*} F_{2}>K_{2}^{*}(1)\end{array}\right.$ \\
\hline 3 & $\begin{array}{c}\text { Republic of } \\
\text { Armenia }\end{array}$ & $N_{3}^{*}$ & $F_{3}=0.100$ & $N_{13}^{*}=\left\{\begin{array}{lll}N_{3}^{*} F_{3}, & \text { если } & N_{3}^{*} F_{3} \leq K_{3}^{*}(1) \\
K_{3}^{*}(1), & \text { если } & N_{3}^{*} F_{3}>K_{3}^{*}(1)\end{array}\right.$ \\
\hline 4 & $\begin{array}{c}\text { Republic of } \\
\text { Belarus }\end{array}$ & $N_{4}^{*}$ & $F_{4}=0.038$ & $N_{14}^{*}=\left\{\begin{array}{lll}N_{4}^{*} F_{4}, & \text { если } & N_{4}^{*} F_{4} \leq K_{4}^{*}(1) \\
K_{4}^{*}(1), & \text { если } & N_{4}^{*} F_{4}>K_{4}^{*}(1)\end{array}\right.$ \\
\hline 5 & $\begin{array}{l}\text { Republic of } \\
\text { Kyrgyzstan }\end{array}$ & $N_{5}^{*}$ & $F_{5}=0.012$ & $N_{15}^{*}=\left\{\begin{array}{lll}N_{5}^{*} F_{5}, & \text { если } & N_{5}^{*} F_{5} \leq K_{5}^{*}(1) \\
K_{5}^{*}(1), & \text { если } & N_{5}^{*} F_{5}>K_{5}^{*}(1)\end{array}\right.$ \\
\hline
\end{tabular}

Source: Compiled by the author. 
6) to determine the remains of the volume $K_{j}$ of labor resources in the states: $K_{j}^{*}(2)=K_{j}^{*}(1)-N_{1 j}^{*}, \quad j=1,2,3,4,5$;

7) make variation series (13) for the third in a row (12) states;

8) make Table 4;

9) to conduct similar constructions for the fourth and fifth in the variation series (12) of the states.

Table 4

The volume of labor resources of the states employed in the third for the variational series of the state

\begin{tabular}{|c|c|c|c|c|c|}
\hline $\begin{array}{l}\text { Number } \\
\text { in the } \\
\text { variant } \\
\text { number }\end{array}$ & $\begin{array}{c}\text { State } \\
\text { name/ } \\
\text { country }\end{array}$ & $\begin{array}{c}\text { The volume } \\
\text { of youth } \\
\text { employed } \\
\text { in the state }\end{array}$ & $\begin{array}{c}\text { Fishburne } \\
\text { rating }\end{array}$ & The & $\begin{array}{l}\text { Olume of labor resources } \\
\text { f the states employed } \\
\text { e third for the variational } \\
\text { series of the state }\end{array}$ \\
\hline 1 & $\begin{array}{c}\text { Russian } \\
\text { Federation }\end{array}$ & $N_{1}^{*}$ & $F_{1}=0.600$ & $N_{11}^{*}=$ & $\left\{\begin{array}{lll}N_{1}^{*} F_{1}, & \text { если } & N_{1}^{*} F_{1} \leq K_{1}^{*}(2) \\
K_{1}^{*}(2), & \text { если } & N_{1}^{*} F_{1}>K_{1}^{*}(2)\end{array}\right.$ \\
\hline 2 & $\begin{array}{l}\text { Republic of } \\
\text { Kazakhstan }\end{array}$ & $N_{2}^{*}$ & $F_{2}=0.250$ & $N_{12}^{*}=$ & $\left\{\begin{array}{lll}N_{2}^{*} F_{2}, & \text { если } & N_{2}^{*} F_{2} \leq K_{2}^{*}(2) \\
K_{2}^{*}(2), & \text { если } & N_{2}^{*} F_{2}>K_{2}^{*}(2)\end{array}\right.$ \\
\hline 3 & $\begin{array}{c}\text { Republic of } \\
\text { Armenia }\end{array}$ & $N_{3}^{*}$ & $F_{3}=0.100$ & $N_{13}^{*}=$ & $\left\{\begin{array}{lll}N_{3}^{*} F_{3}, & \text { если } & N_{3}^{*} F_{3} \leq K_{3}^{*}(2) \\
K_{3}^{*}(2), & \text { если } & N_{3}^{*} F_{3}>K_{3}^{*}(2)\end{array}\right.$ \\
\hline 4 & $\begin{array}{c}\text { Republic of } \\
\text { Belarus }\end{array}$ & $N_{4}^{*}$ & $F_{4}=0.038$ & $N_{14}^{*}=$ & $\left\{\begin{array}{lll}N_{4}^{*} F_{4}, & \text { если } & N_{4}^{*} F_{4} \leq K_{4}^{*}(2) \\
K_{4}^{*}(2), & \text { если } & N_{4}^{*} F_{4}>K_{4}^{*}(2)\end{array}\right.$ \\
\hline 5 & $\begin{array}{l}\text { Republic of } \\
\text { Kyrgyzstan }\end{array}$ & $N_{5}^{*}$ & $F_{5}=0.012$ & $N_{15}^{*}=$ & $\left\{\begin{array}{lll}N_{5}^{*} F_{5}, & \text { если } & N_{5}^{*} F_{5} \leq K_{5}^{*}(2) \\
K_{5}^{*}(2), & \text { если } & N_{5}^{*} F_{5}>K_{5}^{*}(2)\end{array}\right.$ \\
\hline
\end{tabular}

Source: Compiled by the author.

Table 5

The national composition of youth employed in each state of the EAEU and the volume of unemployed labor resources of the states

\begin{tabular}{|c|c|c|c|c|c|c|c|c|}
\hline \multirow[t]{2}{*}{ Number } & \multirow{2}{*}{$\begin{array}{c}\text { State } \\
\text { name/ } \\
\text { country }\end{array}$} & \multirow{2}{*}{$\begin{array}{l}\text { The volume } \\
\text { of youth } \\
\text { employed } \\
\text { in the state }\end{array}$} & \multicolumn{5}{|c|}{$\begin{array}{l}\text { The ethnic composition of youth } \\
\text { employed in each EAEU state }\end{array}$} & \multirow{2}{*}{$\begin{array}{l}\text { The vo- } \\
\text { lume of } \\
\text { non-labor } \\
\text { resources }\end{array}$} \\
\hline & & & $N_{1}$ & $N_{2}$ & $N_{3}$ & $N_{4}$ & $N_{5}$ & \\
\hline 1 & $\begin{array}{l}\text { Russian } \\
\text { Federation }\end{array}$ & $N_{1}$ & $N_{11}$ & $N_{12}$ & $N_{13}$ & $N_{14}$ & $N_{15}$ & $K_{1}(5)$ \\
\hline 2 & $\begin{array}{l}\text { Republic of } \\
\text { Kazakhstan }\end{array}$ & $N_{2}$ & $N_{21}$ & $N_{22}$ & $N_{23}$ & $N_{24}$ & $N_{25}$ & $K_{2}(5)$ \\
\hline 3 & $\begin{array}{l}\text { Republic of } \\
\text { Armenia }\end{array}$ & $N_{3}$ & $N_{31}$ & $N_{32}$ & $N_{33}$ & $N_{34}$ & $N_{35}$ & $K_{3}(5)$ \\
\hline 4 & $\begin{array}{l}\text { Republic of } \\
\text { Belarus }\end{array}$ & $N_{4}$ & $N_{41}$ & $N_{42}$ & $N_{43}$ & $N_{44}$ & $N_{45}$ & $K_{4}(5)$ \\
\hline 5 & $\begin{array}{l}\text { Republic of } \\
\text { Kyrgyzstan }\end{array}$ & $N_{5}$ & $N_{51}$ & $N_{52}$ & $N_{53}$ & $N_{54}$ & $N_{55}$ & $K_{5}(5)$ \\
\hline
\end{tabular}

Source: Compiled by the author. 
As a result of the considered procedure, the ethnic composition of the youth employed in each EAEU state and the volume of unemployed labor resources of the states is determined (Table 5). These volumes are equal to the values $K_{1}^{*}(5), K_{2}^{*}(5), K_{3}^{*}(5), K_{4}^{*}(5), K_{5}^{*}(5)$ (Table 4$)$ obtained during the fifth iteration.

\section{Conclusion}

In general, the considered model makes it possible to predict the youth policy determined by the EAEU states, the distribution of youth labor resources, and possible levels of unemployed labor resources. Therefore, it provides a macroeconomic assessment of the volume of youth labor migration in the EAEU states. The results of this assessment can be used to shape a rational youth policy of the EAEU.

\section{References}

Anisiforov A.B., Il'in I.V., Silkina G.Yu., Yur'ev V.N. (2012). Innovative development of the industrial cluster: monograph. Saint Petersburg: Sankt-Peterburgskii politekhnicheskii universitet Petra Velikogo. (In Russ.)

Anisimov V.G., Anisimov E.G. (2007). Optimization model of the distribution of renewable resources in the management of economic systems. Vestnik Rossiiskoi tamozhennoi akademii, (1), 49-54. (In Russ.)

Anisimov V.G., Anisimov E.G., Arslanov R.F., Arslanova A.P., Bogoeva E.M., Goloskokov V.I., Lipatova N.G., Popov V.V., Saurenko T.N., Tebekin A.V. (2015). Economic and customs risk management. Moscow: Rossiiskaya tamozhennaya akademiya. (In Russ.)

Anisimov V.G., Anisimov E.G., Gapov M.R. Rodionova E.S., Saurenko T.N., Silkina G.Yu., Tebekin A.V. (2017). Strategic innovation management: analysis, planning, modeling, decision-making, organization, evaluation. Saint Petersburg. (In Russ.)

Anisimov V.G., Anisimov E.G., Kokhanova N.M., Mal'kova A.L. (2016). The choice of the structure of production functions based on the synthesis of non-alternative statistical hypotheses. Vestnik Rossiiskoi tamozhennoi akademii, (4), 74-79. (In Russ.)

Anisimov V.G., Anisimov E.G., Saurenko T.N. (2015). Methodological bases for assessing the stability of customs unions. Akademicheskii vestnik Rostovskogo filiala Rossiiskoi tamozhennoi akademii, 2(19), 44-46. (In Russ.)

Anisimov V.G., Gorbatov M.Yu., Saurenko T.N. (2013). Model of dynamics of indicators of economic development of interacting states. Vestnik Rossiiskoi tamozhennoi akademii, (2), 33-44. (In Russ.)

Balyasnikov V.V., Vedernikov Yu.V. et al. (2015). Model of causal analysis based on the use of data about special situations. Voprosy oboronnoi tekhniki. Seriya 16: Tekhnicheskie sredstva protivodeistviya terrorizmu, 1-2(79-80), 31-38. (In Russ.)

Blau S.L., Mantusov V.B., Novikov V.E., Petrov V.S., Tebekin A.V., Tebekin P.A. et al. (2017). Innovation Management. Moscow: Rossiiskaya tamozhennaya akademiya. (In Russ.)

Boiko A.P., Kalinina O.V., Karpov V.A., Lobas E.V. et al. (2008). Introduction to economic risk management. Moscow. (In Russ.)

Chernysh A.Ya. et al. (2006). Efficiency of investments. Methodological and methodological foundations. Moscow: Voennaya Ordena Lenina, Krasnoznamennaya, Ordena Suvorova Akademiya General'nogo shtaba vooruzhennykh sil Rossiiskoi Federatsii. (In Russ.)

Chvarkov S.V. (2016). Economic policy in the system of national security of the Russian Federation. Natsional'nye prioritety Rossii, 3(21), 22-32. (In Russ.) 
Chvarkov S.V., Kharchekno E.B. et al. (2017). The Generalized Indicator of the Effectiveness of Interaction between Federal Executive Bodies in Solving the Problems of Ensuring the National Security of a State. Voprosy oboronnoi tekhniki. Seriya 16: Tekhnicheskie sredstva protivodeistviya terrorizmu, 5-6 (107-108), 101-106. (In Russ.)

Il'in I.V. et al. (2018). Mathematical methods and tools for evaluating the effectiveness of investments in innovative projects. Saint Petersburg. (In Russ.)

Likhacheva O.A. et al. (2014). Methodology of a posteriori performance evaluation of scientific and scientific-pedagogical departments of higher educational institutions. Vestnik Rossiiskoi tamozhennoi akademii, (1), 27-32. (In Russ.)

Lipatova N.G., Chernysh A.Ya. et al. (2011) The use of mathematical methods for dissertation research. Moscow: Rossiiskaya tamozhennaya akademiya. (In Russ.)

Rodionova E.S., Saurenko T.N., Tebekin A.V., Tebekin P.A. et al. (2016). Theoretical Foundations of Innovation Management. Saint Petersburg. (In Russ.)

Saurenko T.N. et al. (2019). Methodical approach to modeling the formation of plans for innovative development of enterprises. Zhurnal issledovanii po upravleniyu, 5(1), 65-72. (In Russ.)

Serba V.Ya. (2014). The development of female entrepreneurship in the Russian Federation in the post-crisis period. In L.I. Smirnova (ed.), Gosudarstvennoe upravlenie i sotsial'nokul'turnaya sfera $v$ XXI veke: zakonomernosti $i$ osobennosti funktsionirovaniya, traditsii i innovatsii: Materialy II Mezhdunarodnoi nauchno-prakticheskoi konferentsii (pp. 126-129). (In Russ.)

Serba V.Ya., Noskov G.E. (2015). Personality activity factors of economic training in the system of higher education: monograph. Saint Petersburg. (In Russ.)

Silkina G.Yu. (2010). Regional Aspects of Innovation Development. Innovatsii v upravlenii regional'nym i otraslevym razvitiem: Sbornik nauchnykh trudov (pp. 146-151). Tyumen'. (In Russ.)

Silkina G.Yu. (2018). Tools and methods of project management of cultural and humanitarian business support in the fuel and energy sector. In V.V. Plenkina (ed.), Innovatsii v upravlenii regional'nym $i$ otraslevym razvitiem: Materialy Vserossiiskoi nauchnoprakticheskoi konferentsii c mezhdunarodnym uchastiem (pp. 161-165). (In Russ.)

Silkina G.Yu., Shevchenko S.Yu. (2018). Capital of public acceptability as a tool for managing business internationalization processes. Vestnik fakul'teta upravleniya SPbGEU, 3(1), 216-221. (In Russ.)

\section{Article history:}

Received: 12.04.2019

Revised: 30.05.2019

Accepted: 20.07.2019

\section{For citation:}

Veselko A.A. (2019). Methodical approach to assessing the volume of youth labour migration in the states of the Eurasian Economic Union. RUDN Journal of Economics, 27(3), 576-586. http://dx.doi.org/10.22363/2313-2329-2019-27-3-576-586

\section{Bio note:}

Alena A. Veselko, assistant of the Customs Department, Faculty of Economics, Peoples' Friendship University of Russia (RUDN University). E-mail: petrochenko-aa@rudn.ru 


\title{
Методический подход к оценке объемов трудовой миграции молодежи в государствах ЕАЭС
}

\author{
А.А. Веселко \\ Российский университет дружбы народов, \\ Российская Федераиия, 117198, Москва, ул. Миклухо-Маклая, 6
}

Трудовая миграция играет немаловажную роль в социально-экономическом развитии любого государства. Это связано с тем, что она оказывает влияние как на структуру, так и на численность, на социальную и хозяйственную сферы жизни общества. Следовательно, миграционные процессы необходимо отслеживать, так как в дальнейшем это может положительно сказаться на экономическом росте страны. В статье предложена модель для макроэкономической оценки объемов трудовой миграции молодежи в государствах Евразийского экономического союза (ЕАЭС). Основу модели составляет представление трудовой миграции в виде случайного марковского процесса с дискретными состояниями и непрерывным временем. Состояния цепи интерпретируются как рынки труда молодежи соответствующих государств ЕАЭС, а интенсивности переходов отражают привлекательность этих рынков для молодежи различных государств, что позволяет учесть присущие процессу миграции молодежи неопределенность и инерционность.

Ключевые слова: Евразийский экономический союз; рынки труда; молодежная трудовая миграция; методический подход; прогнозирование; оценка

\section{История статьи:}

Дата поступления в редакцию: 12.04.2019

Дата проверки: 30.05.2019

Дата принятия к печати: 20.07.2019

\section{Для цитирования:}

Veselko A.A. Methodical approach to assessing the volume of youth labour migration in the states of the Eurasian Economic Union (Методический подход к оценке объемов трудовой миграции молодежи в государствах ЕАЭС) // Вестник Российского университета дружбы народов. Серия: Экономика. 2019. Т. 27. № 3. С. 576-586. http://dx.doi.org/10.22363/2313-2329-2019-27-3-576-586

\section{Сведения об авторе:}

Веселко Алена Александровна, ассистент кафедры таможенного дела, экономический факультет, Российский университет дружбы народов. E-mail: petrochenko-aa@rudn.ru 